\title{
Land Value Model in Potential Areas of Surabaya-Middle East Ring Road
}

\author{
Gatot Subroto \\ Department of Architecture \\ Inatitut Teknologi Sepuluh Nopember Indonesia
}

\author{
Adjie Pamungkas \\ Department of Urban and Regional Planning \\ Inatitut Teknologi Sepuluh Nopember Indonesia
}

\author{
Eko Budi Santoso \\ Department of Urban and Regional Planning Inatitut Teknologi \\ Sepuluh Nopember Indonesia
}

\begin{abstract}
Over time, the value and price of urban land will increase as an effect of the improvement of urban areas, such as road infrastructure. Reviews: These condition caused each location to have different accessibility of each land. When choosing a place to settle, human tend to choose a location with high level of accessibility in order to facilitate their mobility. The aim of this research is to determine the model of urban land value due to the establishment of Surabaya-Middle East Ring Road based on spatial linear regression. The aim of this research is attained through the following stages: (1) analyzing the pattern of land price dynamics of Surabaya-Middle East Ring Road area; (2) analyzing the variables that impact the value and price of land in SurabayaMiddle East Ring Road.

This research used a quantitative approach that is based on positivist paradigm. The method used is using spatial linear regression analysis. The analysis validation models are supported by using the method of variance calculation error and Kalman Filtering. The number of variables that influence is as much as 18 variables, but which has significantly higher value is 11 variables. The samples selected were as many as 201 samples. Acquired land value model has high accuracy values, is 0.08 (the error variance) and 0.58 (Kalman Filtering). So the model can be used as a predictive model of land prices in 2027.
\end{abstract}

Keywords-Land Value; Land Price; Linear Spatial Regression; Ring Road.

\section{I, INTRODUCTION}

Land is a part of the landscape, which has spatial properties as well as the location human activity. The phenomenon of land demand tends to increase in line with the population growth. Every aspect of life and development, both are directly and directly related to the issue of land [1]

Changes in urban land use are influenced by four main processes - i.e. the expansion of the network infrastructure, particularly transport links, as well as the growth and loss of concentration of certain activities. Thus, it could be indicated that there is a relationship between the development of land use with the development of transportation network.

The rise of land price is influenced by investment in development. There are six kinds of investment in development that have the different increase value. Road construction and expansion of transportation modes have the most significant increase rate, which is $12.90 \%$, whereas the other five investments have lower rates, i.e. land plot regulation (6.60\%), improvement of drinking water and sewerage system (3.38\%), urban planning and land development (3.04\%), construction of public facilities $(0.97 \%)$, and the expansion of the area $(0.56 \%)$. Hence, the construction of road infrastructure could be indicated affect the value of urban land and the economy of the city significantly.

Based on the investment report of East Java 2014-2015, for the interest of investment location, Surabaya held the fifth rank for Foreign Direct Investment (FDI) with an investment value of 2.01 Trillion. It is 3\% from the total value of investment in East Java and held the $7^{\text {th }}$ rank for domestic investment. The amount, which is 0.8 Trillion, is $2 \%$ of the total value of investment in East Java. Surabaya's development is predicted to reach $50 \%$ and possibly could beat Jakarta which is Indonesia's economic center. At the national level, the housing development has not grown rapidly yet but Surabaya's property market has arisen. This evidence is proved by the increase of housing area development by $50 \%$ compared to the situation in 2014 and the construction of 20 apartments in 2015. This amount shows that the vertical housing trend has already occurred in Surabaya.

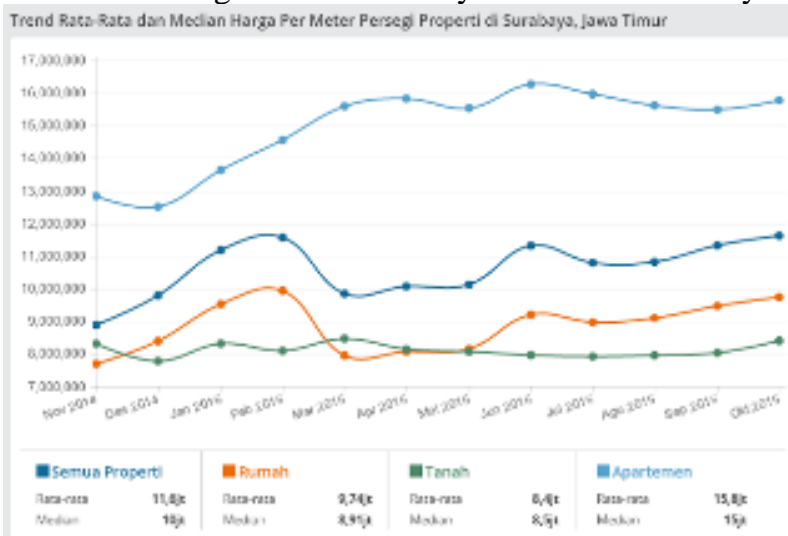

Fig 1. Average Increase in land value in Surabaya from 2014 to 2015

The price of land in the city of Surabaya is increasing, Surabaya Surabaya East Central and land prices have reached a price of 30 million to 50 million. In addition, support transport network plan will also increase the value of investments in the area of Surabaya [5]. However, the current state is still lack of clarity related to the management of land value in Surabaya. It was evident from some of the rules of Surabaya which only requires developers to contribute to the delivery of facilities, 
infrastructure (Surabaya Mayor Regulation Number 57 the Year 2013). So that the contribution of developers still looks favorable to Surabaya. In the Eastern Ring Road development greatly affects the value of the surrounding land, which was originally just under 1 million per $\mathrm{m} 2$. However, after the construction plan, Inner Ring Road East Surabaya with surrounding land prices have also increased. Until now, the increases in land prices reached almost $1000 \%$. In addition, the status of the land around the Inner Ring Road East was once dominated by land owned by local people and some of the developers with the main function as a settlement. After the construction and functioning of the Inner Ring Road East in East Surabaya, the status of land ownership dominated by the developer. With the main function now becoming trade and services as well as some settlements [6]. From the explanation above, it could be concluded that the effect of Middle East Ring Road to the land value is very huge. Therefore, in order to provide more benefit and better management, the optimization of land value is needed.

\section{II, METHODOLOGY}

\section{A Population}

The population that is studied is the whole research area, which covers four subdistricts. In total, the area covers \pm 575.23 Ha.

I. Rungkut Kidul subdistrict (area \pm 145.39 ha), consisted of 12 (twelve) RW

II. Kedung Baruk subdistrict (area \pm 148.93 ha), consisted of 9 (nine) RW

III. Penjaringan Sari subdistrict (area \pm 175.80 ha), consisted of 11 (eleven) RW

IV. Kali Rungkut subdistrict (area \pm 105.09 ha), consisted of 8 (eight) RW

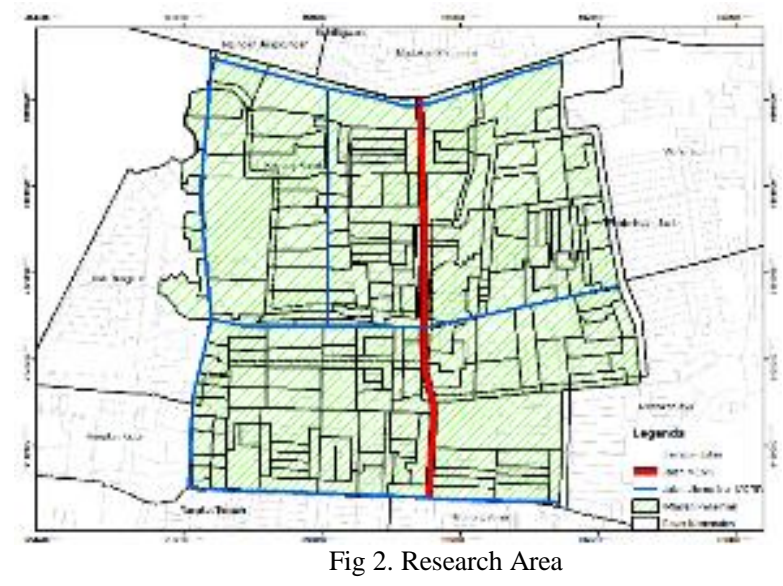

\section{B, Sample}

The sampling technique that was used is the proportional method. This method is also known as proportional random sampling method. Sampling using cluster sampling technique adjusted to the determination of the Land Value Zone. In determining the initial land value zone, the technique that was used is by picking a sample zone that represent the main radius of the inner eastern ring road. The area around this ring road is named as an area that is rapidly developed. At this step, the approach that is used to define the radius is based on a study by Sawitri (2017), that used $1 \mathrm{~km}$ from the eastern inner ring road.
Beside that this research also combined the administrative territory approach named "RT" (rukun tetangga), which stands for Indonesia's smallest neighborhood unit. Based on the analysis that has been done, 201 land value zones were obtained. Those are located in Rungkut Kidul subdistrict, Kedung Baruk subdistrict, Penjaringan Sari subdistrict, and Kali Rungkut subdistrict.

From the initial land value zone is then carried out a search process of land price data using interview techniques to zone 201 above. Interviews were conducted with the main character of each zone, namely RT. Because in the process of buying and selling or measurement, the RT is always involved. Interviews were conducted with the main character of each zone, namely RT. Because in the process of buying and selling or measurement, the RT is always involved. Interviews were conducted with the main character of each zone, namely RT. Because in the process of buying and selling or measurement, the RT is always involved.

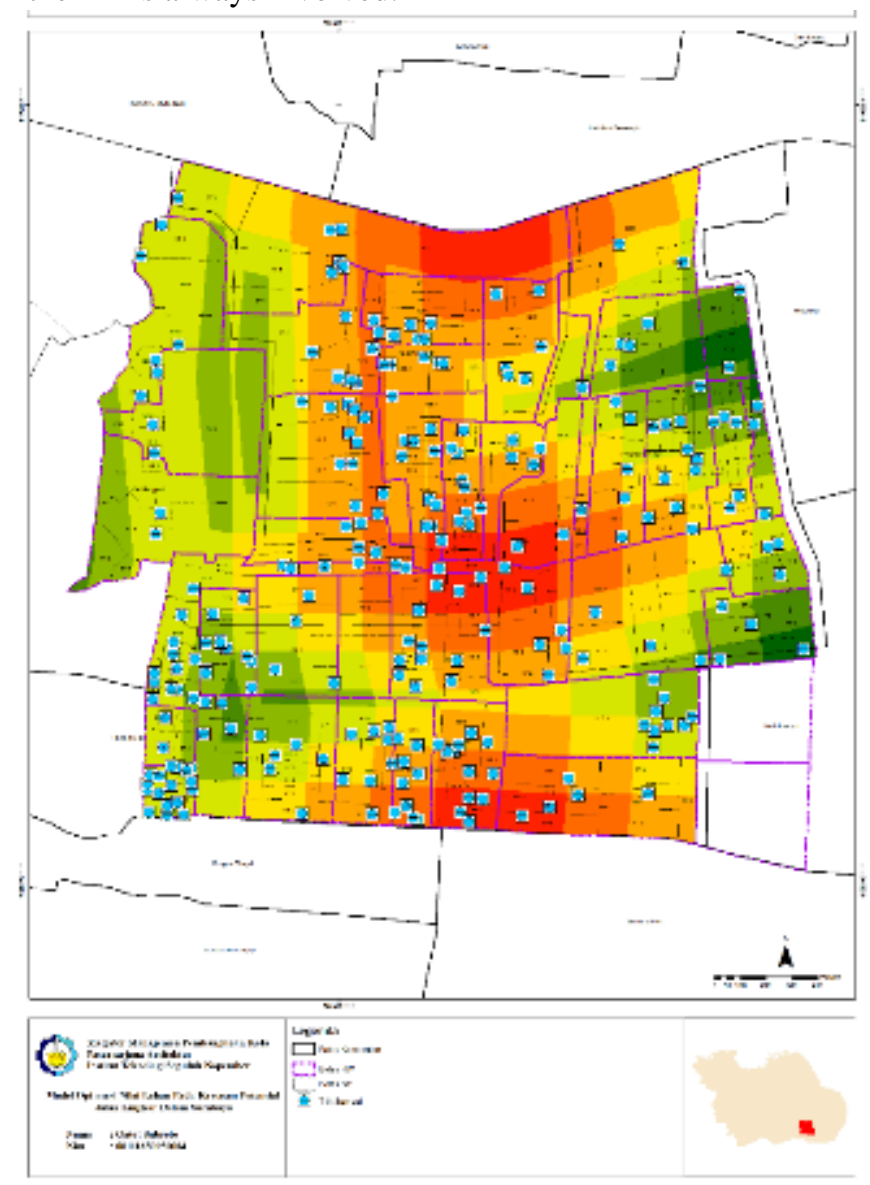

Fig 2. Sample point spread

\section{C, Stages of Analysis}

TABLE 1. Stage of Analysis

\begin{tabular}{|c|l|l|c|l|}
\hline No. & \multicolumn{1}{|c|}{ Target } & \multicolumn{1}{|c|}{ input Data } & \multicolumn{1}{c|}{$\begin{array}{c}\text { Mechanical } \\
\text { Analysis }\end{array}$} & \multicolumn{1}{c|}{ output } \\
\hline 1 & $\begin{array}{l}\text { Analyzing the } \\
\text { pattern of land } \\
\text { price pattern of } \\
\text { Inner Ring } \\
\text { Road area of } \\
\text { East Surabaya }\end{array}$ & $\begin{array}{l}\text { Prices in 2007 and } \\
\text { the existing land in } \\
\text { the vicinity of the } \\
\text { eastern ring road }\end{array}$ & Comparison & $\begin{array}{l}\text { Map } \\
\text { developme } \\
\text { nt land } \\
\text { value }\end{array}$ \\
& & & \\
\hline
\end{tabular}




\begin{tabular}{|c|c|c|c|c|}
\hline No. & Target & input Data & $\begin{array}{l}\text { Mechanical } \\
\text { Analysis }\end{array}$ & output \\
\hline 2 & $\begin{array}{l}\text { Identifying the } \\
\text { variables that } \\
\text { affect the value } \\
\text { of the land }\end{array}$ & $\begin{array}{l}\text { The results of the } \\
\text { questionnaire that } \\
\text { contains the values } \\
\text { for the following } \\
\text { variables: } \\
\text { - Land Use } \\
\text { - The distance by } \\
\text { road } \\
\text { - The distance to } \\
\text { the means of } \\
\text { transport } \\
\text { - Distance with } \\
\text { These Public } \\
\text { Transport } \\
\text { - Distance to the } \\
\text { Activity Center } \\
\text { - Distance to the } \\
\text { Office } \\
\text { - Distance to the } \\
\text { trade in services } \\
\text { - Distance } \\
\text { education } \\
\text { - The distance to } \\
\text { the health } \\
\text { facility } \\
\text { - The distance to } \\
\text { the waste } \\
\text { facility } \\
\text { - The distance to } \\
\text { the water } \\
\text { network } \\
\text { - The distance to } \\
\text { the drainage } \\
\text { network } \\
\text { - pool } \\
\text { - KDB value } \\
\text { - value outbreak } \\
\text { - SVTO } \\
\text { Building density }\end{array}$ & $\begin{array}{c}\text { Confirmatory } \\
\text { Factor } \\
\text { Analysis }\end{array}$ & $\begin{array}{l}\text { Factors } \\
\text { that } \\
\text { influence } \\
\text { the value } \\
\text { of the land }\end{array}$ \\
\hline 3 & $\begin{array}{l}\text { Building a } \\
\text { spatial model } \\
\text { of land prices } \\
\text { in the area of } \\
\text { Inner Ring } \\
\text { Road East } \\
\text { Surabaya }\end{array}$ & $\begin{array}{l}\text { 1. Map of the } \\
\text { distribution of } \\
\text { the value of } \\
\text { existing land } \\
\text { 2. Factors affect } \\
\text { the value of } \\
\text { land in the area } \\
\text { of Surabaya } \\
\text { JLDT }\end{array}$ & $\begin{array}{c}\text { Spatial } \\
\text { Linear } \\
\text { Regression } \\
\text { Analysis }\end{array}$ & $\begin{array}{l}\text { Model of } \\
\text { land prices } \\
\text { in the area } \\
\text { around } \\
\text { JLDT } \\
\text { Surabaya }\end{array}$ \\
\hline
\end{tabular}

D. Identification of factors that affect the land value Before performing the factor analysis, at first the author conducted a preliminary survey to test the validity and reliability of the questionnaire. For this stage selected respondents are chosen by using analysis of stakeholders. According to Raharjo (2014), a questionnaire is valid if it fulfill these criteria:

- $\quad \mathrm{R}$ arithmetic $>\mathrm{R}$ table $\rightarrow$ invalid

- $\quad \mathrm{R}$ count $<\mathrm{R}$ table $\rightarrow$ invalid

In addition, research questionnaire:

- $\quad$ Alpha $>\mathrm{R}$ table $\rightarrow$ reliable / consistent

- Alpha $<\mathrm{R}$ table $\rightarrow$ unreliable / inconsistent
If the pilot questionnaire has already met the validity and reliability criteria, then it could be used for the entire sample. Next, to analyze the result from the questionnaire a technique called confirmatory factor analysis (CFA) is used.

By using CFA a priori someone is already situated knowing the concept and theory. He/she also knows how many factors that should be formed, including the latent variables that is included in those factors that are going to be confirmed to the respondents. Below is a diagram that shows the process of doing factor analysis.

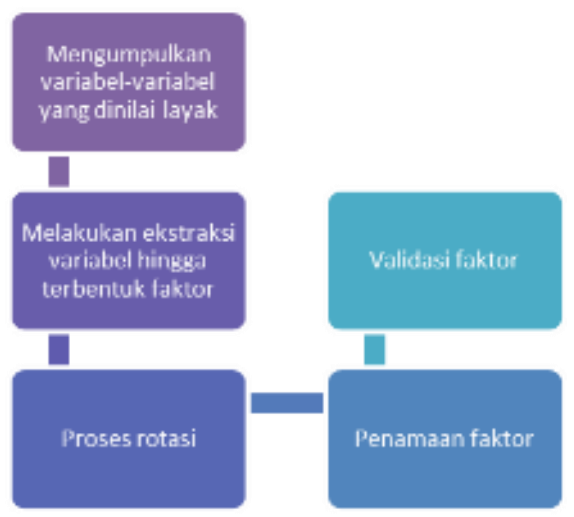

Fig 3. Analysis CFA

\section{E. Construction of spatial model .}

The next process is to analyze the influence of these factors on each sample by using the spatial linear regression (SLR). By using this technique the most influential factor that becomes the major determinant of the influence of changes in land valued could be discovered. In this study the land value is defined as the dependent variable (Y), while the independent variables are the ones that influence the land value based on the reduction process using CFA.

Spatial Linear Regression (SLR) method is method that is used to estimate the classical regression coefficient by minimizing the sum of squared error that minimizes $\sum_{1}^{n}=$ $1 \varepsilon_{i}^{2}$.

Estimator in the of SLR method is obtained by minimizing.

$$
\Sigma=\Sigma(Y i-\beta 0-\beta 1 X i 1-\beta 2 X i 2-\ldots-\beta k X i p) 2 \varepsilon_{i}^{2}
$$

With $\Sigma$ is the sum of squared errors (JKG). $\varepsilon_{i}^{2}$

In matrix notation the sum of squared errors, $\Sigma$ dapat written as $\varepsilon_{i}^{2}$

$$
\begin{gathered}
\varepsilon_{1}^{\prime} \varepsilon_{i}=\left[\begin{array}{llll}
\varepsilon_{1} & \varepsilon_{2} & \ldots & \varepsilon_{n}
\end{array}\right]\left[\begin{array}{c}
\varepsilon_{1} \\
\varepsilon_{2} \\
\vdots \\
\varepsilon_{n}
\end{array}\right]=\varepsilon_{1}^{2}+\varepsilon_{2}^{2}+\cdots+\varepsilon_{n}^{2}=\sum \varepsilon_{i}^{2} \\
\boldsymbol{\varepsilon}=\boldsymbol{Y}-\boldsymbol{X} \boldsymbol{\beta}
\end{gathered}
$$

Therefore, the error matrix multiplication into

$$
\begin{aligned}
J=\varepsilon_{i}^{\prime} \varepsilon_{l} & =(\boldsymbol{Y}-\boldsymbol{X} \boldsymbol{\beta})^{\prime}(\boldsymbol{Y}-\boldsymbol{X} \boldsymbol{\beta}) \\
& =\left(\boldsymbol{Y}^{r}-\boldsymbol{\beta}^{\prime} \boldsymbol{X}^{\prime}\right)(\boldsymbol{V}-\boldsymbol{X} \boldsymbol{\beta}) \\
& =\boldsymbol{Y}^{\prime} \boldsymbol{Y}-\boldsymbol{Y}^{\prime} X \boldsymbol{\beta}-\boldsymbol{\beta}^{\prime} \boldsymbol{X}^{\prime} \boldsymbol{Y}+\boldsymbol{\beta}^{\prime} X^{\prime} X \boldsymbol{\beta} \\
& =\boldsymbol{Y}^{\prime} \boldsymbol{Y}-2 \boldsymbol{Y}^{\prime} \boldsymbol{X} \boldsymbol{\beta}+\boldsymbol{\beta} X^{\prime} \boldsymbol{\beta} \boldsymbol{\beta}
\end{aligned}
$$


or in full if it is written in matrix notation into

$$
\begin{aligned}
\left(X^{\prime} \boldsymbol{X}\right) \widehat{\boldsymbol{\beta}} & =\boldsymbol{X}^{\prime} \boldsymbol{Y} \\
\left(\boldsymbol{X}^{\prime} \boldsymbol{X}\right)^{-1}\left(\boldsymbol{X}^{\prime} \boldsymbol{X}\right) \widehat{\boldsymbol{\beta}} & =\left(\boldsymbol{X}^{\prime} \boldsymbol{X}\right)^{-1} \boldsymbol{X}^{\prime} \boldsymbol{Y} \\
\boldsymbol{I} \boldsymbol{\beta} & =\left(\boldsymbol{X}^{\prime} \boldsymbol{X}\right)^{-1} \boldsymbol{X}^{\prime} \boldsymbol{Y} \\
\widehat{\boldsymbol{\beta}} & =\left(\boldsymbol{X}^{\prime} \boldsymbol{X}\right)^{-1} \boldsymbol{X}^{\prime} \boldsymbol{Y}
\end{aligned}
$$

SLR is a regression method that minimizes the number of squared errors. The linear regression model that is used in that SLR must fulfill the BLUE (best linear unbiased estimator) assumption in performing the prediction of interval and parameter test of population regression. Below are several BLUE assumptions:

a. The regression model is linear in its parameters.

b. Independent variables are not stochastic (has a fixed value for repetitive sample) and there is no exact linear relationship between two or more variables are free (no-multicollinearity).

c. error term or error has a zero expected value, E ( $\varepsilon i)=$ 0

d. error term or have a constant variance for all observations (homoskedasticity), $\mathrm{E}(\varepsilon 2)=\sigma 2$

e. error term or an error on an observation unrelated to the error term in another observation. (noautocorrelation)

f. error term or error normal distribution.

\section{F. Model Validation}

Model validation can be done by performing several test in which the result should represent the field's reality. There are several test that must be performed, such as testing the limits of the variable, the validity and reliability of each units that are used, multi-collinearity, and test of data field accuracy (Barlas in Pamungkas, 2012). The first one is to test the limits of exploration of the variables that are used in constructiong the model. This test was done through an interview process that involved 221 respondents who have sufficient knowledge on land values. Annex II shows the analysis techniques that was used for the variable limit selection.

The second phase is to test the validity and reliability of each unit of the obtained variebles. This second test was carried out on a discussion sub-chapter 4.3, namely the validity of the each unit is more than $\mathrm{R}$ count, which means that each unit is valid. Meanhwile the reliability test result that is obtained is 0.686 for KMO value $(>0.5), 0.000$ for significance value $(<0.5)$, and the MSA value of each variable unit is $>0.5$. Thus, each unit could be said consistent. The last test is the model accuracy test that was done by using the field data.

\section{III, DISCUSSION}

A. Analysis of Development Pattern

In 2007 the land value zone is divided 195 zone. The average value of the highest ground in 2007 is located in zone 76 and zone 112. Both are located in Kali Rungkut sub district and Kedung Baru sub district. The value of both land is $\mathrm{Rp} 10,000,000 / \mathrm{m} 2$. Meanwhile the lowest average price could be found in in zone 74 and zone 75 that are located in Kali Rungkut sub district, which ist at Rp200,000/m2. The zone map that shows the land value in 2007 is shown below.
In 2017 the land value zone is also divided into 195 zones. The average value of the highest ground in 2017 is located in zone 3, which is located in the village Networking Sari with the land value of Rp. 100,000,000 / m2. And the average price was lowest for the first zone which is at Rungkut Kidul village, which amounted to Rp. 1,500,000 / m2

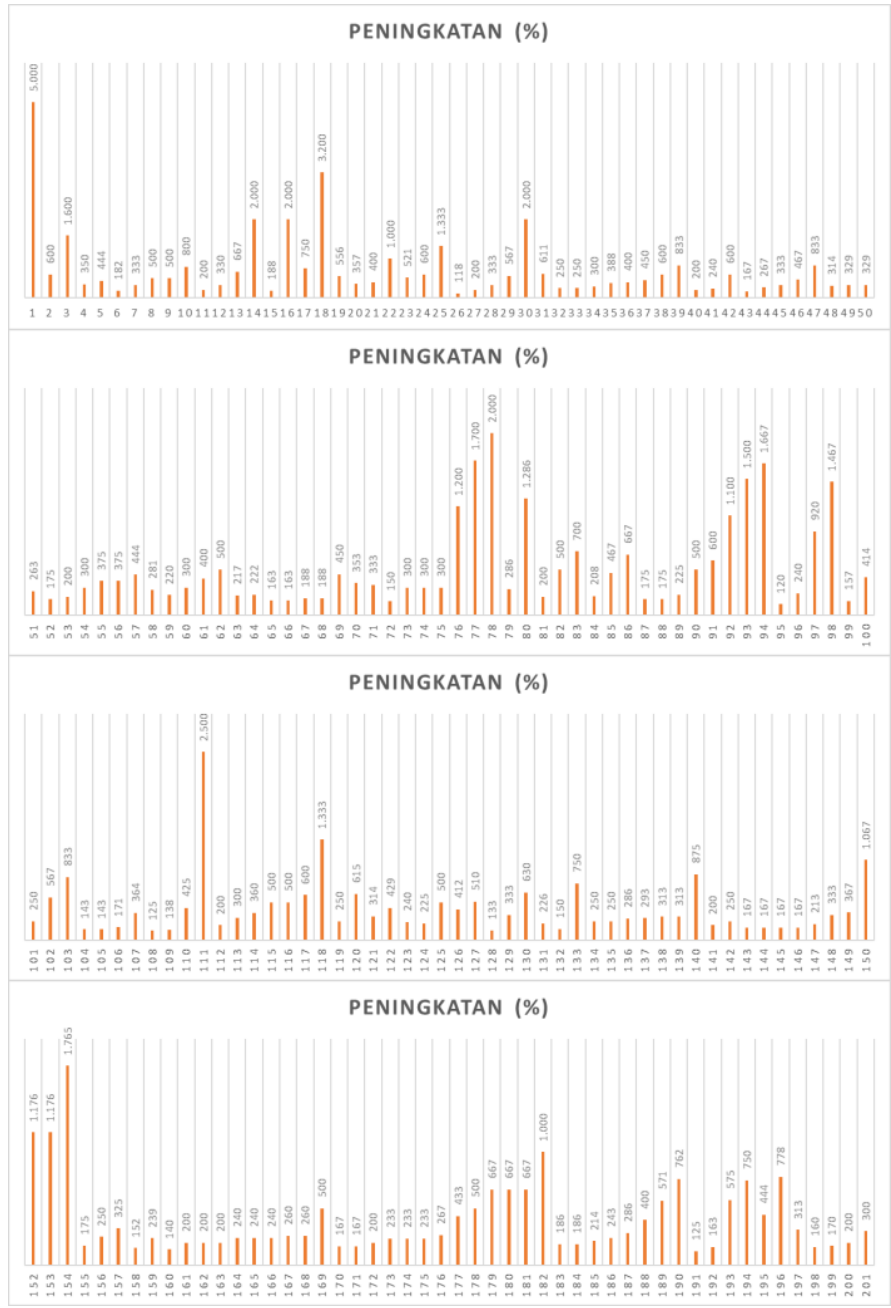

Fig 4. Increased land value

The next step of this research is analyzing the development pattern of land value by doing a comparison between the proximity to road value and land change that occurred between 2007 and 2017. The development pattern of land value zone is obtained by conducting road radius analysis for road that are wider than $15 \mathrm{~m}$. This number $(15 \mathrm{~m})$ was chosen because at 15 $\mathrm{m}$ the area has a high investment potential value, and the policy on space usage intensity is high, too. Below is the development pattern of land value in several zones.

TABLE 2. The pattern of Changes in Land Values

\begin{tabular}{|c|c|l|l|r|}
\hline $\begin{array}{c}\text { Radius with } \\
\text { the Way }\end{array}$ & $\begin{array}{c}\text { zon } \\
\text { e }\end{array}$ & \multicolumn{1}{|c|}{$\begin{array}{c}\text { Land Use In } \\
2007\end{array}$} & Land Use In 2017 & $\begin{array}{r}\text { Percentag } \\
\text { e }\end{array}$ \\
\hline \multirow{5}{*}{$0-250 \mathrm{~m}$} & 16 & Housing & $\begin{array}{l}\text { Trade and } \\
\text { Services }\end{array}$ & $1214 \%$ \\
\cline { 2 - 5 } & 44 & Housing & $\begin{array}{l}\text { Trade and } \\
\text { Services }\end{array}$ & $175 \%$ \\
\cline { 2 - 5 } & 36 & Housing & $\begin{array}{l}\text { Trade and } \\
\text { Services }\end{array}$ & $267 \%$ \\
\cline { 2 - 5 } & 57 & Housing & $\begin{array}{l}\text { Trade and } \\
\text { Services }\end{array}$ & $188 \%$ \\
\hline
\end{tabular}




\begin{tabular}{|c|c|c|c|c|}
\hline $\begin{array}{l}\text { Radius with } \\
\text { the Way }\end{array}$ & $\begin{array}{c}\text { zon } \\
\mathrm{e}\end{array}$ & $\begin{array}{c}\text { Land Use In } \\
2007\end{array}$ & Land Use In 2017 & $\begin{array}{r}\text { Percentag } \\
\mathrm{e}\end{array}$ \\
\hline & 171 & Housing & $\begin{array}{l}\text { Trade and } \\
\text { Services }\end{array}$ & $575 \%$ \\
\hline & 195 & Housing & $\begin{array}{l}\text { Trade and } \\
\text { Services }\end{array}$ & $429 \%$ \\
\hline & 159 & Housing & $\begin{array}{l}\text { Trade and } \\
\text { Services }\end{array}$ & $667 \%$ \\
\hline & 166 & $\begin{array}{l}\text { Green open } \\
\text { space }\end{array}$ & $\begin{array}{l}\text { Trade and } \\
\text { Services }\end{array}$ & $400 \%$ \\
\hline \multirow{6}{*}{$251-500 \mathrm{~m}$} & 100 & Housing & Housing & $500 \%$ \\
\hline & 71 & $\begin{array}{l}\text { Green open } \\
\text { space }\end{array}$ & $\begin{array}{l}\text { Trade and } \\
\text { Services }\end{array}$ & $3000 \%$ \\
\hline & 169 & $\begin{array}{l}\text { Green open } \\
\text { space }\end{array}$ & Housing & $200 \%$ \\
\hline & 115 & Housing & $\begin{array}{l}\text { Trade and } \\
\text { Services }\end{array}$ & $150 \%$ \\
\hline & 191 & Housing & $\begin{array}{l}\text { Trade and } \\
\text { Services }\end{array}$ & $286 \%$ \\
\hline & 10 & $\begin{array}{l}\text { Green open } \\
\text { space }\end{array}$ & $\begin{array}{l}\text { Trade and } \\
\text { Services }\end{array}$ & $1000 \%$ \\
\hline \multirow{6}{*}{$501-750 \mathrm{~m}$} & 87 & Empty land & Housing & $920 \%$ \\
\hline & 12 & $\begin{array}{l}\text { Green open } \\
\text { space }\end{array}$ & Housing & $2000 \%$ \\
\hline & 167 & $\begin{array}{l}\text { Green open } \\
\text { space }\end{array}$ & Housing & $571 \%$ \\
\hline & 74 & Empty land & Housing & $800 \%$ \\
\hline & 102 & Empty land & Housing & $600 \%$ \\
\hline & 8 & $\begin{array}{l}\text { Green open } \\
\text { space }\end{array}$ & $\begin{array}{l}\text { Trade and } \\
\text { Services }\end{array}$ & $800 \%$ \\
\hline \multirow{2}{*}{$\begin{array}{l}751-1000 \\
m\end{array}$} & 60 & $\begin{array}{l}\text { Green open } \\
\text { space }\end{array}$ & Housing & $333 \%$ \\
\hline & 46 & $\begin{array}{l}\text { Green open } \\
\text { space }\end{array}$ & Housing & $300 \%$ \\
\hline
\end{tabular}

In conclusion the land use change that occurred and followed with the construction of new roads will increase the land value at any point, especially with altered land on the of the land use hierarchy.

\section{B. Factor that Affect the Land Value in Potential Roundabout Areas in East Surabaya}

To be able to analyze the factors that influenced the land value of JLDR potential area, a technique called confirmatory factor analysis (CFA) was used. Based on the theoretical review that has been done before, there are 4 factors which is consisted of variables that indicated influenced the land price. The factor and variables are as follow:

TABLE 3. Variable Code

\begin{tabular}{|c|l|l|c|}
\hline No. & \multicolumn{1}{|c|}{ Factor } & \multicolumn{1}{|c|}{ variables } & Code \\
\hline 1. & Land prices & Market price & Y \\
\hline 2. & accessibility & $\begin{array}{l}\text { The distance to the } \\
\text { road network }\end{array}$ & A1 \\
\cline { 4 - 5 } & & $\begin{array}{l}\text { The distance to the } \\
\text { means of transport }\end{array}$ & A2 \\
\cline { 4 - 5 } & $\begin{array}{l}\text { Distance to the } \\
\text { Office }\end{array}$ & A3 \\
& $\begin{array}{l}\text { Distance to public } \\
\text { transport routes }\end{array}$ & A4 \\
\cline { 3 - 5 } & $\begin{array}{l}\text { The distance to the } \\
\text { center of activity }\end{array}$ & A5 \\
\cline { 3 - 5 } & $\begin{array}{l}\text { Distance to the trade } \\
\text { in services }\end{array}$ & A6 \\
\cline { 3 - 5 } & $\begin{array}{l}\text { The distance to the } \\
\text { water network }\end{array}$ & A7 \\
\cline { 3 - 5 } & $\begin{array}{l}\text { Distance to } \\
\text { educational facilities }\end{array}$ & A8 \\
\cline { 3 - 5 } & $\begin{array}{l}\text { The distance to the } \\
\text { health facility }\end{array}$ & A9 \\
\hline
\end{tabular}

\begin{tabular}{|c|l|l|c|}
\hline No. & \multicolumn{1}{|c|}{ Factor } & \multicolumn{1}{|c|}{ variables } & Code \\
\hline \multirow{2}{*}{3.} & \multirow{2}{*}{\begin{tabular}{l} 
Physical \\
condition \\
\cline { 3 - 4 }
\end{tabular}} & waste facility & A10 \\
\cline { 3 - 4 } & & Land Use & F1 \\
\cline { 3 - 4 } & & Drainanant conditions & F2 \\
\hline \multirow{2}{*}{4.} & \multirow{2}{*}{$\begin{array}{l}\text { Government } \\
\text { policy }\end{array}$} & KDB Policy & F3 \\
\cline { 3 - 4 } & & KLB Policy & P1 \\
\cline { 3 - 4 } & SVTO Policy & P2 \\
\hline 5 & Social & Building density & S1 \\
\hline
\end{tabular}

After the encoding process is done, it is followed by the validity and reliability test.

a. Validity test

In this test, the number of respondents that partake are 201 person, with a significance level at $95 \%$. Thus the obtained $\mathrm{R}$-table value is 0.1538 . Based on the test result, the value of $\mathrm{R}$-count is more than 0.1538 .

TABLE 3. R-count Value

\begin{tabular}{|l|l|l|l|}
\hline variables & R-Count & variables & R-Count \\
\hline A1 & 0493 & F1 & 0425 \\
\hline A2 & 0594 & F2 & 0439 \\
\hline A3 & 0463 & F3 & 0575 \\
\hline A4 & 0517 & F4 & 0604 \\
\hline A5 & 0189 & P1 & 0461 \\
\hline A6 & 0158 & P2 & 0483 \\
\hline A7 & 0531 & P3 & 0254 \\
\hline A8 & 0480 & P4 & 0272 \\
\hline A9 & 0646 & P5 & 0189 \\
\hline A10 & 0567 & S1 & 0346 \\
\hline
\end{tabular}

\section{b. Reliability test}

The result shows that the obtained alpha value is 0.799 . Thus, the questionnaire could be claimed reliable. It can be used as analytical tool to answer the research objectives.

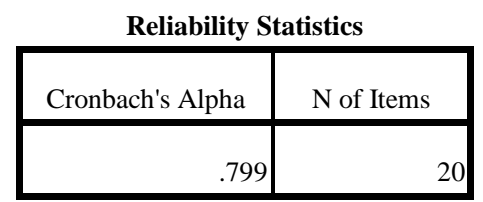

\section{The development model of land value in a potential area $J L D T$}

a. Land Value Model of 2017

The land price trend model that is developed by using the input from variables of obtained factors from the second objective and sample points of land price from the first objective, since they provide the most recent information. Then to determine the land value trend in JLDT potential area, the author did spatial linear regression analysis by using geographic information system (GIS) software named ArcGIS (version 10.4). This process is continued with a multiple regression analysis by using SPSS. 


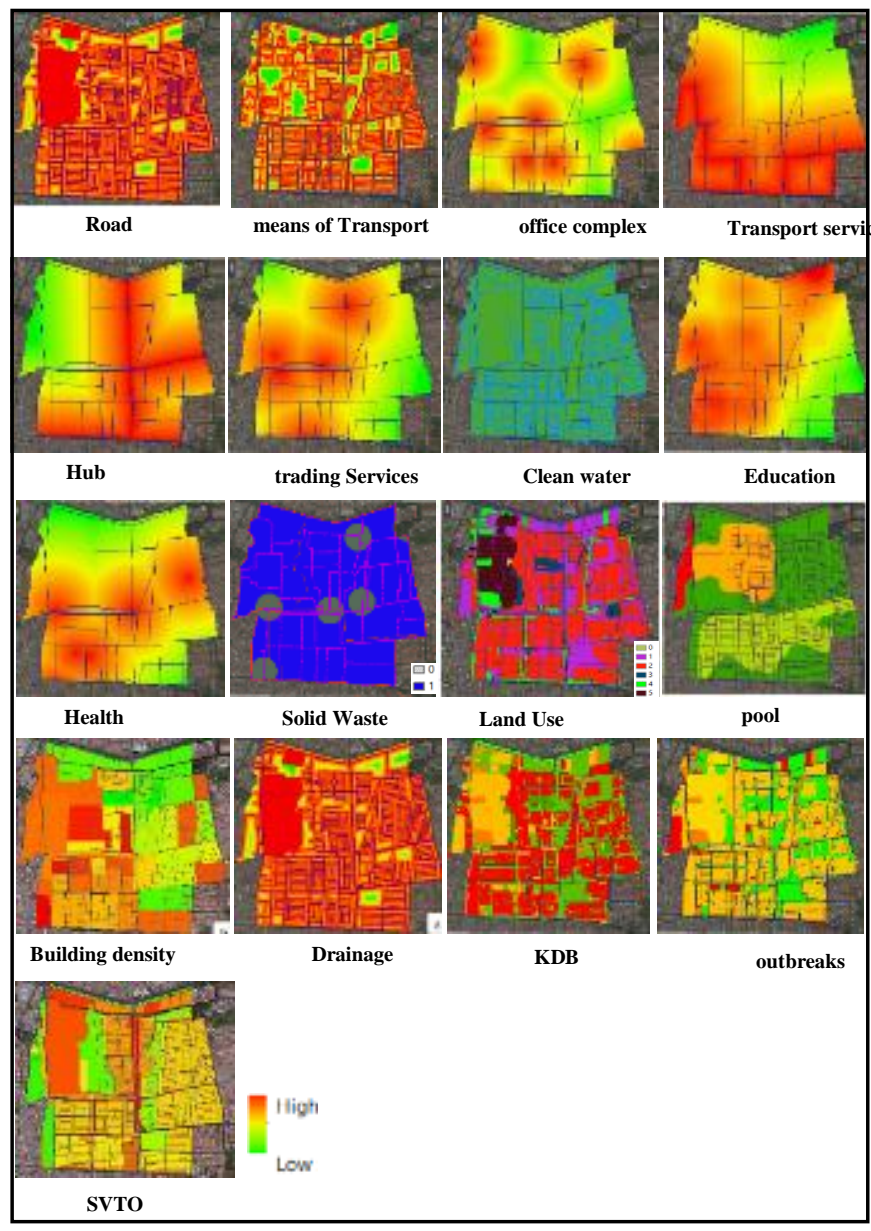

Fig 4. Variable Value in 2017

The spatial linear regression is developed by using the stepwise method. This method is a combination of both forward and backward regression method.

\begin{tabular}{|l|r|r|r|r|r|}
\hline \multirow{2}{*}{ Model } & \multicolumn{1}{|c|}{ Coefficientsa } \\
\cline { 2 - 6 } & \multicolumn{1}{|c|}{ Coefficients unstandardized } & $\begin{array}{r}\text { standardized } \\
\text { Coefficients }\end{array}$ & \multicolumn{1}{c|}{$\mathrm{t}$} & \multicolumn{1}{c|}{ Sig. } \\
\hline (Constant) & \multicolumn{1}{|c|}{ B } & \multicolumn{1}{c|}{ Std. Error } & beta & & \\
A4 & $-56175,768$ & 2970873.002 & & 10851 & .000 \\
A8 & 10230.282 & 1681.196 & .623 & 6,085 & .000 \\
P2 & 6312426.260 & 633897.787 & .320 & 9958 & .000 \\
P1 & $-146361,160$ & 22034.367 & -.342 & -6642 & .000 \\
A1 & $-24252,077$ & 4414.613 & -.685 & -5494 & .000 \\
F1 & 48485.562 & 14447.316 & .097 & 3356 & .001 \\
P3 & 1097852.313 & 311709.703 & .078 & 3,522 & .001 \\
A5 & 13393.686 & 2640.548 & .427 & 5,072 & .000 \\
A9 & -9410.891 & 2953.863 & -.294 & -3186 & .002 \\
F2 & $-1426562,483$ & 537422.995 & -.059 & -2654 & .009 \\
\hline
\end{tabular}

a. Dependent Variable: $Y$

Based on the table above, 7 models are obtained by using the stepwise method. The best model is the seventh one, thus the formula for land value in the research area is as follow:
$Y=32.240 .000-56.175,768 \mathrm{~A} 4+10.230,282 \mathrm{~A} 8+6.312 .426,260 \mathrm{P} 2$ $146.361,160 \mathrm{P} 1-24.252,077 \mathrm{~A} 1+48.485,562 \mathrm{~F} 4+1.097,852,313 \mathrm{P} 3+$ 13.393.686 A5 - 9.410.891 A9 - 1.426.562.438 F2

Here is a map of land value model result in 2017

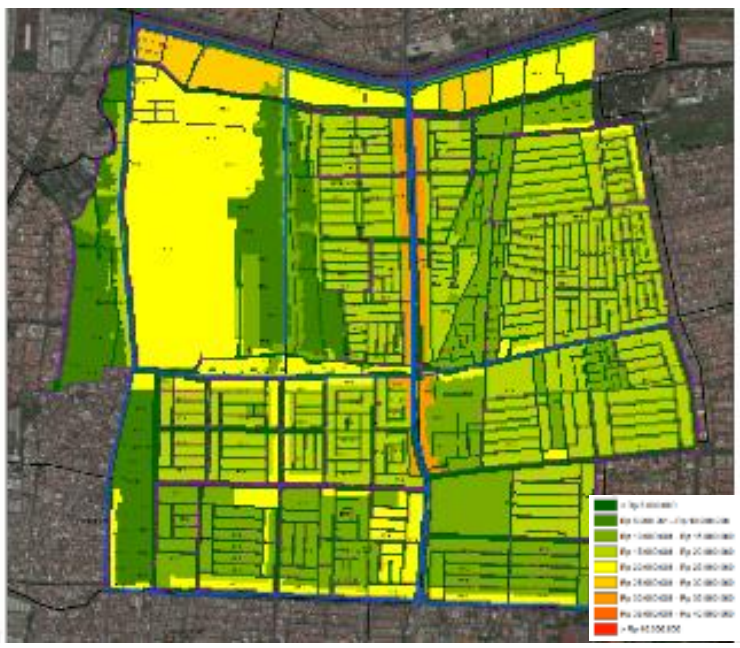

Fig 5. Results of Land Value Model 2017

\section{b. Model Validation for Land Value of 2017}

Model validation could be done by performing several test (Sterman in Pamungkas, 2012) and the resulted model should represent the reality of the field. The model could be declared invalid if the calculation of error variance and index value are both less than 0.1. Beside that the model should also fulfill the criteria of Kalman Filtering. A model could be said strong when the Kalman Filtering calculation result is close to 0.5. The result of variance error and Kalman Filtering is shown below:

\begin{tabular}{|c|c|c|c|c|}
\hline Year & Data Fields & $\begin{array}{c}\text { Results } \\
\text { Model }\end{array}$ & $\begin{array}{c}\text { Kalman } \\
\text { Filtering }\end{array}$ & $\begin{array}{c}\text { error } \\
\text { Variance }\end{array}$ \\
\hline 2017 & 2814216700 & 3067333806 & 0.521517889 & 0.089942294 \\
\hline
\end{tabular}

\section{c. Land Value Model of 2027}

Based on the regression model that is generated from the previous sub-chapter, the process is continued with the calculation of a model to predict the situation in 2027 by analyzing the variables that changed, such as SVOT, land use plan, building coverage ratio, floor area ration, and expansion of each road that exist in the research area. After the change value of each variable based on the issued plan and policy is obtained, the next step is redoing the spatial linear regression.

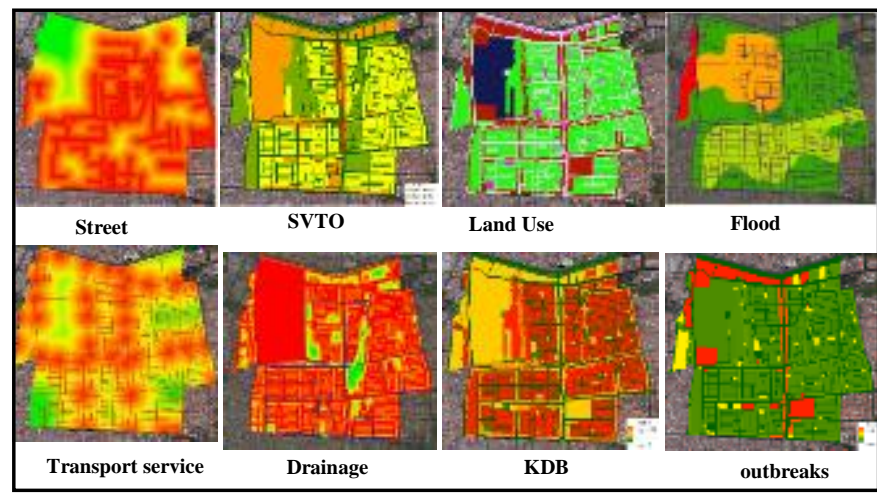

Fig 6. Variable Value in 2027 
Changes in the value of the variable in 2027, then showed the value of land in 2027 as follows.

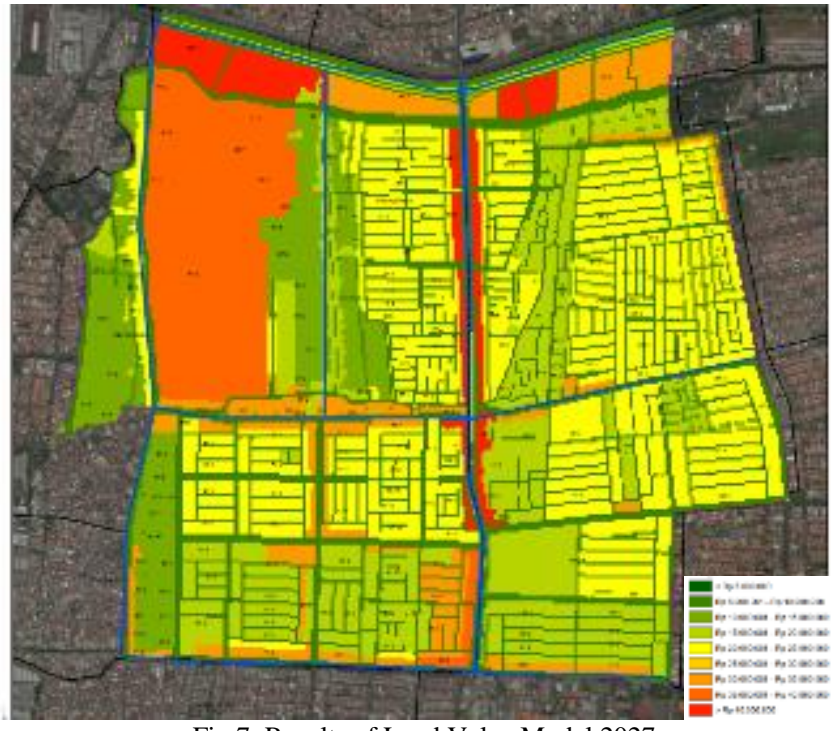

Fig 7. Results of Land Value Model 2027

The result that is obtained from both 2017's and 2027's land value model is going to be processed again by using the land price increase analysis. The land price's increase rate starts from Rp4 to Rp19,382,048. However if it is change into percentage, the value range is from $0 \%$ to $100 \%$.

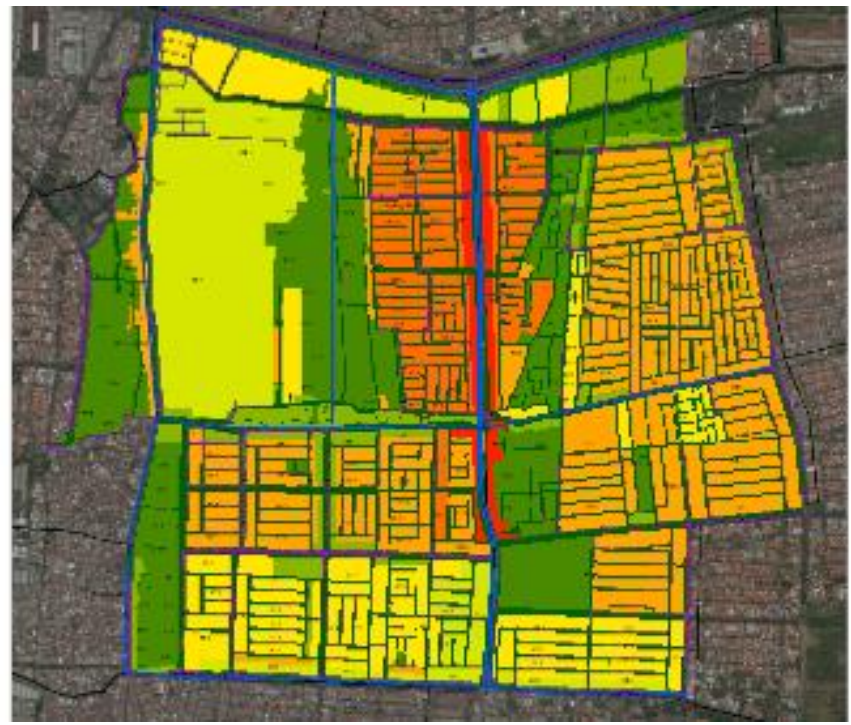

Rp 4 - Rp 152.020

Rp 152.021 - Rp 608.068 $\square$ Rp 608.069 - Rp 1.292 .141 $\square$ Rp 1.292.142 - Rp 1.672.181 Rp 1.672 .182 - Rp 3.040 .325 Rp 3.040.326 - Rp 3.992.980 Rp 3.992.981 - Rp 9.765 .158 Rp 9.765.159 - Rp 19.382 .048

Fig 8. Increase in Land Value from 2017 to 2027

\section{IV, CONCLUSION}

As a conclusion, the development of infrastructure in the region will affect the land value changes. In determining the value zone, each land has its own pattern of land value. The highest land values tend to be located on main road corridor and commercial areas. In this research the corridor along Jl. Ir. Soekarno (MERR) is followed with Kedung Baruk corridor and industrial area. The land value that was developed by using Stepwise method with 11 variables that have high values, including market price, road proximity, mass transportation proximity, education and health care facilities proximity, inundation condition, and BCR (building coverage ratio), FAR (floor area ratio), and SVTO.

The obtained SLR model has high accuracy value, which is 0.08 for the error of variance and 0.58 for Kalman Filtering. Hence, this model can be used to predict the land value in 2027. For the 2027 land value model, the highest value that is reached is Rp64,867,987.47 and averagely increased by $41.09 \%$. It means that the variable value's change from 2017 to 2027 contributed to an increase of $41.09 \%$.

\section{ACKNOWLEDGMENT}

Author GS would like to thank his lecturers: Mr. Adjie Pamungkas and Mr. Eko Budi Santoso, for the insightful discussion during the whole research. The author would also thank to other parties that have contributed, particularly the Indonesia's Directorate of Higher Education that has awarded the author a master scholarship.

\section{REFERENCES}

[1] Chapin, Stuart, Edward J. Kaiser. 1979 Urban Land Use Planning. University of Illinois Press. London.

[2] Mayasari, Karina et al. 2009. Factors Affecting Land Prices in Special Region-Based Industries and New Town City Center Samarinda. Malang: Brawijaya University.

[3] Wolcott, Richard C. 1987. The Appraisal of Real Estate American Institute of Real Estate Appraiser. North Michigan, Chicago Illinois.

[4] Rahmawati, 2016. Development Land Prices Surabaya. Urban Indo. Surabaya

[5] Navastara, Ardy M., and Navitas, Prananda. 2012. Towards Impact of Residential Development Land Price Dynamics in Surabaya ResearchGate Publication.

[6] Syara, Aulia. Road Construction Impact Mount Anyar MERR IIC Progress Against HaRGA Land. 2016. ITS. Surabaya. 